
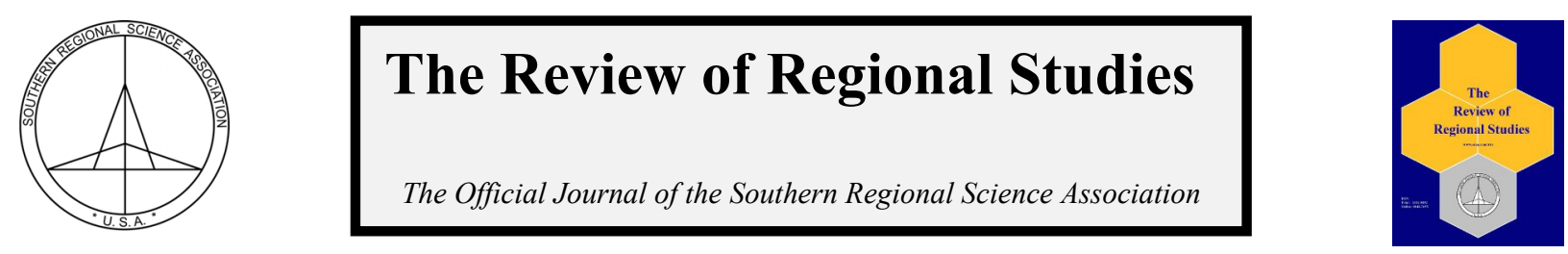

\title{
Community Banks and Agricultural Sales in Rural States ${ }^{*}$
}

\author{
Jeffrey K. O'Hara \\ U.S. Department of Agriculture, Agricultural Marketing Service, Washington, DC
}

\begin{abstract}
The consolidation of the commercial banking sector may influence the viability of farms in accessing credit. I estimate the influence that changes in the level of deposits in community banks had on total agricultural sales and direct-to-consumer agricultural sales of local food between 2002 and 2012 in a five-state region containing North Dakota, South Dakota, Minnesota, Wyoming, and Montana. I find that changes in community bank deposits had a positive impact on changes in direct-to-consumer agricultural sales of local foods, while total agricultural sales may not be impacted by changes in community bank deposits.
\end{abstract}

Keywords: community banks, local foods, agricultural finance

JEL Codes: G21, Q14, R11

\section{INTRODUCTION}

"Community" banks are banks with limited size, limited geographic scope, are privately and/or locally owned, and have a primary business model of lending to small businesses and agricultural operations with local deposits (FDIC, 2012). A comparative advantage that community banks may possess is their knowledge of local market conditions and personal relationships with borrowers. In recent decades, the number of community banks has declined sharply with a corresponding decrease of their market share in the commercial banking sector (FDIC, 2012). Since community banks have a prominent role in providing credit to farms, changes to the structure of the commercial banking sector could affect agricultural markets. In particular, farms for which personal relationships with lenders may be important for credit access, such as farms selling through nontraditional markets, could be adversely impacted when credit through community banks becomes less available. Understanding how trends in the commercial banking sector affect farming segments can inform the development of policies that are intended to bolster credit availability and promote the development of markets for such farms.

I employ county-level panel data to estimate the influence that changes in the level of deposits in community banks have on total agricultural sales and direct-to-consumer (DTC) agricultural sales that occur at farmer's markets and other direct marketing outlets between 2002 and 2012. I estimate these impacts in a five-state region containing North Dakota, South Dakota, Minnesota, Montana, and Wyoming. This region is of interest for several reasons. First, these contiguous states have low population densities; thus, farms in the region likely depend highly on community banks for accessing credit. Second, these states experienced a relatively high increase

\footnotetext{
${ }^{*}$ The author appreciates helpful comments from participants at the $55^{\text {th }}$ Southern Regional Science Association Annual Meeting. The views expressed are those of the author and should not be attributed to the U.S. Department of Agriculture.

O'Hara is an Agricultural Marketing Specialist in the U.S. Department of Agriculture's Agricultural Marketing Service, Washington, DC. E-mail: jeffreyk.ohara@ams.usda.gov
}

C) Southern Regional Science Association 2017.

ISSN 1553-0892, 0048-749X (online)

www.srsa.org/rrs 
in the share of agricultural sales occurring from large farms between 2002 and 2012; meanwhile DTC agricultural sales declined between 2007 and 2012 despite a pronounced increase in per capita income. These trends could have been influenced by the simultaneous consolidation of the commercial banking sector. Third, there was variation in the trends of community bank deposits within the region during this period which, as I discuss in the Background section below, could be attributed to different levels of institutional support available to community banks.

I find that community bank deposits have a positive and statistically significant influence on DTC agricultural sales. This could happen because community bank loans may be critical in bolstering nontraditional markets for smaller farms that opt not to compete directly with large farms in conventional markets. I further find that total agricultural sales may be unaffected by changes in the level of community bank deposits. This could occur because local knowledge possessed by community banks is less essential in evaluating loans for farms that sell commodities into national or global markets. I find that community bank deposits may be endogenous with respect to total agricultural sales, but are otherwise exogenous.

Previous research has found that credit constraints can have an adverse impact on a farm's financial performance (Briggeman, Towe, and Morehart, 2009; Sabasi and Kompaniyets, 2015). This implies that a decline in the availability of credit from community banks may have an adverse impact on farms for which personal relationships are of relatively greater importance. Nonetheless, whether these effects are pronounced is not well understood. For example, Gloy, Gunderson, and Ladue (2005) find that while the costs to lenders fall when lenders have a longer relationship with a borrower and provide a greater share of a borrower's debt, the impact is modest.

An important contribution of this research is to use a recent Federal Deposit Insurance Corporation (FDIC) community banking classification scheme to examine how changes in community bank deposits influence the value of agricultural production. Prior to this definition, banking size was typically used as a proxy to identify a "community bank." Another innovation is how I estimate changes in the way that the commercial banking sector influences agricultural sales from farms that use unconventional marketing channels. Few studies have examined the trends between the banking sector and DTC agricultural markets.

The paper is organized in the following manner. The next section discusses trends in the commercial banking sector, trends in agricultural markets, and sources of farm credit. This is followed by a description of the empirical model, potential causes of endogeneity, and data sources. The subsequent section presents results of instrumental variable (IV) regressions and first difference (FD) regressions for both total agricultural sales and DTC agricultural sales specifications. The final sections discuss the results and offer concluding comments.

\section{BACKGROUND}

\subsection{Community Banks}

Community banks depend critically on relationship lending that is premised on a high degree of knowledge of their community and borrowers (Tarullo, 2014). Community banks have a prominent market share in providing loans to agricultural operations, small businesses, and for residential mortgages (Lux and Greene, 2015). Prior to the development of the FDIC definition of community banks (FDIC, 2012), researchers typically relied on the size of the bank as a proxy for community banks. However, this method fails to account for the bank's business model.

(C) Southern Regional Science Association 2017. 
The criteria for the FDIC community bank classification include limited asset-size, limited geographic scope, a threshold level of lending and deposit gathering relative to total assets, limited assets in foreign offices, and a limited level of assets held in specialty banking charters. Deposits are a reasonable proxy for credit availability from community banks because the FDIC community bank definition entails that such banks must have a loan-to-asset ratio of at least 33 percent and a core deposit-to-asset ratio of at least 50 percent. In practice, however, community banks can have such ratios well in excess of the FDIC minimum thresholds; this suggests that deposits can be highly correlated with lending activity. For instance, U.S. community banks had a loan-to-asset ratio of 67 percent and a core deposit ratio of 79 percent in March 2016. These percentages were only 52 percent and 61 percent, respectively, for all other banks (FDIC, 2015c).

The commercial banking sector consolidated considerably in recent decades. There were less than half of the number of community banks in the U.S. in 2011 as there were in 1987, and the percentage of banking assets held by community banks declined from 38 percent in 1984 to 14 percent in 2011 (FDIC, 2012). Their decline in market share accelerated further between 2010 and 2014 (Lux and Greene, 2015).

Small banks generally account for a relatively low share of deposits in densely populated states, and vice versa in sparsely populated states like North Dakota, South Dakota, and Montana (Kodrzycki and Elmatad, 2011). North Dakota has more banks per capita than any other U.S. state: South Dakota, Minnesota, Montana, and Wyoming also have more banks per capita than the U.S. average (ILSR, 2015).

North Dakota experienced the largest increase in community bank deposits of the five states in the study region between 2007 and 2012 of $\$ 4$ billion. Among these states, it also had the fastest growth in community bank deposits between 2002 and 2012, 73 percent. North Dakota's more robust presence in community banking relative to these other states may be due to the presence of the Bank of North Dakota (BND), the only state-owned bank in the U.S. A predominate objective of the BND is to enhance the amount of credit that community banks are able to offer (Kodrzycki and Elmatad, 2011). Nevertheless, all community banks in the study region are able to interact with cooperatively-owned "bankers' banks" for similar services.

\subsection{Trends in Agricultural Markets}

The proportion of agricultural production occurring on larger farms has increased across the U.S. in recent decades (MacDonald, Korb, and Hoppe, 2013). Nontraditional markets have emerged for small farms that may be unwilling or unable to compete with large farms in conventional markets. In particular, DTC agricultural sales, which constitute the sale of unprocessed foods directly to humans for final consumption at farmer's markets and other direct marketing channels, doubled in the U.S. from \$0.7 billion in 1992 to \$1.4 billion in 2012 (USDA, 2014). DTC agricultural sales mostly derive from small and medium-sized farms (Ahearn and Sterns, 2013; Low and Vogel, 2011).

Policymakers have developed grant and loan programs to support DTC agricultural markets as an economic development strategy. This is because local food farms are relatively more labor-intensive (Low and Vogel, 2011) and the localized economic impacts of DTC agricultural sales may be relatively higher than food sales from traditional retail outlets, like grocery stores (Hughes et al., 2008; Hughes and Isengildina-Massa, 2015). Still, the extent to which DTC agricultural markets have proliferated varies regionally across the U.S., and in the Plains and 
Rocky Mountain regions they are not an important component of total agricultural sales (Brown et al., 2014).

The five states in this study experienced a relatively high increase in the share of sales from large farms between 2002 and 2012. In 2002, total agricultural sales in the region was $\$ 24$ billion, with 43 percent from farms with at least $\$ 500,000$ in sales. By 2012 , these figures were $\$ 50$ billion and 76 percent, respectively. In contrast, the share of sales from farms of this magnitude during the same period rose by 17 percentage points in the rest of the U.S.

While these five states accounted for 12 percent of total agricultural sales nationally in 2012, they accounted for just 4 percent of DTC agricultural sales. DTC agricultural sales in the five study-region states increased from $\$ 46$ million in 2002 to $\$ 61$ million in 2007, although subsequently declined to $\$ 55$ million in 2012. O'Hara and Low (2016) found that per capita income was a positive and statistically significant predictor of DTC agricultural sales in the Northeast between 1992 and 2012. North Dakota, South Dakota, Montana, Wyoming, and Minnesota experienced the first, third, tenth, eleventh, and sixteenth greatest increases in per capita income among U.S. states during the 2007-2012 time period, respectively. Thus, the decline in DTC agricultural sales between 2007 and 2012 in this region do not appear to have been driven by shifts in demand that were evident in the Northeast, but rather by other factors.

\subsection{Agricultural Financing}

Commercial banks accounted for 42 percent of total farm-sector debt in 2014 (USDA ERS, 2015). ${ }^{1}$ As the commercial banking sector consolidated, agricultural lending from commercial banks increasingly emanated through larger banks (Kauffman and Akers, 2013). Nonetheless, Lux and Greene (2015) found that community banks provided 77 percent of agricultural loans from the commercial banking sector in 2014 , with community banks having less than $\$ 1$ billion in assets providing 55 percent of the loans. They also found that agricultural loans from community banks increased between 2010 and 2014, whereas agricultural loans from the five largest commercial banks simultaneously declined. Further, agriculture comprises a larger share of the loan portfolio of community banks than it does of larger banks (GAO, 2012).

Pertinent factors for small business lending include the competitiveness of the local lending market, the financial performance of local small businesses, and the profitability of other local lenders (Kravchenko, Weiler, and Phillips, 2011). Research examining the importance of relationships on agricultural lending has come up with mixed results. Gloy, Gunderson, and Ladue (2005) find that agricultural lenders charge higher interest rates on smaller loans due to higher perdollar servicing costs and offer lower interest rates to farmers when they have a greater familiarity of farmers' business plans and collateral. They further find that servicing and monitoring costs fall for lenders when they have longer-standing relationships with the borrower and when the proportion of total debt that they extended is greater. Nonetheless, they find that the magnitude of these cost savings is modest.

Research in other contexts finds that relationships can be important in lending. Kandrac (2014) notes that economic impacts resulting from bank failures are not as negative when losssharing agreements are implemented so that an acquiring institution retains the existing bank's customers. Further evidence of the important of relationships in lending is that loans from rural

\footnotetext{
${ }^{1}$ The Farm Credit System, a government-sponsored enterprise consisting of cooperative associations that serve broad geographic areas, accounted for 40 percent of the debt.
}

(C) Southern Regional Science Association 2017. 
community banks to small businesses default less frequently than do urban ones, with a reduced default rate when the lender and borrower are located in the same county (DeYoung et al., 2012). Nonetheless, even if relationships can be important in lending, it does not imply that opaque small businesses are more likely to have a community bank as their main banking resource (Berger, Goulding, and Rice, 2014).

The impact of credit availability on market performance is critical, as credit-constrained farms have a reduced value of production and/or profitability (Briggeman, Towe, and Morehart, 2009; Sabasi and Kompaniyets, 2015). Further, various classes of farmers have different access to credit. Government subsidies are increasingly targeted to larger farms and higher-income households (White and Hoppe, 2012). Government subsidies both facilitate access to credit and also substitute for credit. As a consequence, unsubsidized farms experience greater declines in production value due to credit constraints than do subsidized farms (Briggeman, Towe, and Morehart, 2009). Further, production subsidies, which primarily are directed to nonperishable commodity crops, have contributed to increases in both average farm size (Key and Roberts, 2007) and the share of production from larger farms (Roberts and Key, 2008) by providing both funds or greater ease in obtaining credit to purchase capital.

Credit access may be particularly challenging for farms selling through DTC agricultural markets. This is because production subsidies and crop insurance, which can be collateral for an operating loan, are less available to these farmers (O'Hara, 2012). Beginning farmers also experience financing constraints (Hartarska and Nadolnyak, 2012). Thus, it takes lenders with high levels of institutional and local knowledge to help such farmers.

\section{METHODS}

\subsection{Model}

I estimate an FD model as specified in Equation (1) using pooled ordinary least squares.

$$
y_{t}-y_{t-1}=\left(X_{t}-X_{t-1}\right) \alpha+Z \beta+\varepsilon_{t}-\varepsilon_{t-1}
$$

In Equation (1), the dependent variable is represented by $y$. The independent variables are represented by $X$ and $Z$, with corresponding parameters $\alpha$ and $\beta$. For each period $t$, the vector $y$ has dimension $n \times 1$, where $n$ is the number of counties. The matrix $X$ contains independent variables that vary over time and the matrix $Z$ contains independent variables that do not vary over time. Estimating an FD equation controls for the possibility that time-invariant factors may be correlated with the error term. I examine changes across two five-year time periods: between 2002 and 2007 and between 2007 and 2012. ${ }^{2}$ I estimate Equation (1) using total agricultural sales and DTC agricultural sales as dependent variables.

The independent variable of interest is the change in deposits held by community banks. I include dummy variables as controls for the states of North Dakota, Minnesota, Montana, and Wyoming; nonmetropolitan rural and nonmetropolitan urban regions; and the time interval between 2007 and 2012. I exclude dummy variables corresponding to the State of South Dakota, counties in metropolitan areas, and the time interval between 2002 and 2007.

\footnotetext{
${ }^{2}$ I eliminate Minnehaha County in South Dakota from the sample. Wells Fargo Bank and Citibank are both headquartered in that county, so their deposits there are disproportionately large.
}

(C) Southern Regional Science Association 2017. 
Some of the changes in sales from farms during this period could have been due to price changes. This issue may be more pronounced in parts of the region in which pasture land was converted into cropland in response to increases in crop prices. To control for this, I also include the change in the proportion of farmland in a county that was harvested cropland as an independent variable. I further include an intercept as an independent variable, which corresponds to a time trend in an FD regression.

Omitted variable bias could arise in the specification with DTC agricultural sales as the dependent variable if an increase in community bank deposits is occurring due to an increase in population or per capita personal income, and these latter variables are also increasing the demand for DTC agricultural products. Thus, I also include per capita income and population as additional control variables in the DTC agricultural sales specification. O'Hara and Low (2016) found income to be an exogenous variable with regard to DTC agricultural sales.

I perform several robustness checks to assess the sensitivity of the DTC agricultural sales results to alternate specifications. First, I estimate a specification in which I interact the time, nonmetro urban, and nonmetro rural dummy variables with community bank deposits. This informs whether community bank deposits have differential impacts on DTC agricultural sales in counties with different population densities or in different time periods. Second, I estimate the model in the two distinct periods in order to examine the differential impacts of all of the independent variables on DTC agricultural sales in both periods. Third, I estimate a model in which community bank deposits in neighboring counties are included as an independent variable. I construct this independent variable by creating a symmetric $n \times n$ matrix in which an element takes the value of 1 if two counties in the study region are contiguous to each other and 0 otherwise. Next, I row-standardize the matrix so that each element in a row is divided by the sum of the elements of the row. Finally, I create the independent variable by multiplying this spatial weights matrix by the $n \times 1$ vector of changes in community bank deposits.

\subsection{Endogeneity Tests}

The potential for endogeneity exists if changes in community banking deposits are responding to changes in agricultural markets. For example, community banks may make a concentrated effort to attract deposits in a region if they perceive there are profitable lending opportunities or deposits could increase because of an increase in agricultural sales, the latter of which is likely to be a possibility in regions where agriculture is prominent.

I test for endogeneity using three instruments. First, I use oil production as an instrument, since oil production increased during the 2000s in the Bakken formation in this region due to the improvement in extraction technologies. Support for the use of oil production as an instrument is that the coefficient for oil production, when included as an independent variable along with the other control variables, is statistically insignificant when regressed on either total agricultural sales or DTC agricultural sales as dependent variables. Further rationale for the use of the instrument is that the geographic size of an oil well is modest relative to the amount of land used for agriculture. Also, since oil is an input for agriculture and an increase in oil production could reduce oil prices, the modest size of the region's oil production relative to global supplies implies that the increase in oil withdrawals in the region did not prevent oil prices from increasing during the period of study. I further hypothesize that oil production is correlated with changes in the deposits at community banks since the increase in oil extraction during the study period contributed to sharp increases in per capita income. This increased income, in turn, could increase banking deposits. 
I also use the five-year lag of community bank deposits as an instrument. This instrument may be exogenous with regards to agricultural sales since changes in lagged community bank deposits occurred prior to changes in agricultural sales. Still, since the time-lag is relatively short, I also employ a third instrument- the average state-level change in community bank deposits. The rationale for this instrument is that county-level community banking trends may be correlated with state-level community banking trends. Also, I assume agricultural sales are exogenous since the large geographic size of these states implies that farmers may be less likely to utilize community bank branches in distant geographic regions.

I perform Hausman tests for whether community bank deposits are exogenous. For each specification, I regress community bank deposits on the instruments and other control variables. I then use the residuals from this first-stage regression as an independent variable in specifications in which agricultural sales is also regressed on all of the explanatory variables included in the population model. A statistically significant coefficient corresponding to the first-stage residuals in the second-stage regression indicates that community bank deposits are endogenous (Wooldridge, 2002).

\subsection{Data}

Agricultural sales, harvested cropland acreage, and farm acreage data is available at the county-level in five year intervals from the U.S. Department of Agriculture's Census of Agriculture (USDA, 2014). The U.S. Department of Agriculture's Economic Research Service (USDA ERS) publishes county-level data on oil production (USDA ERS, 2014). I use changes in oil production between 2007 and 2011 as a proxy for changes between 2007 and 2012, since 2011 is the most recent year for which county-level oil production is available in this dataset. USDA ERS also maintains rural-urban continuum codes (USDA ERS, 2013). Population and per capita personal income data are available from the Bureau of Economic Analysis (BEA, 2015). I convert pecuniary data into 2014 U.S. dollars using the Consumer Price Index (BLS, 2015).

Branch-level data on the level of banking deposits is available from the FDIC (2015a). The FDIC's guidance to commercial banks on procedures on how to allocate deposits to a particular branch office are that they must be consistent with the bank's internal record keeping practices. Examples of assignment procedures include the office in closest proximity to the account holder's address, office where the deposit account is most active, or office where the account was originated (FDIC, 2015b). The FDIC (2015c) also classifies whether a bank is a "community" bank or not, and this classification is revised quarterly.

County-level DTC agricultural sales increased, on average, by $\$ 19,000$ during the sample period (Table 1). While community bank deposits increased on average by $\$ 39$ million, the variation between the minimum and maximum was pronounced. Table 1 also shows that there is a balanced representation among the counties in the five states of the sample-almost half of the counties in the sample reside in nonmetropolitan rural areas. There were also pronounced rises in per capita income and average annual oil production in these counties during the study's period.

(c) Southern Regional Science Association 2017. 
Table 1: Descriptive Statistics

\begin{tabular}{|c|c|c|c|c|}
\hline Variable & Mean & Std. Dev. & Min. & Max. \\
\hline \multicolumn{5}{|c|}{ Dependent Variables (\$000) } \\
\hline Change in Total Agricultural Sales & 44,461 & 53,336 & $-431,096$ & 278,872 \\
\hline Change in DTC Agricultural Sales & 19 & 215 & $-1,229$ & 1,440 \\
\hline \multicolumn{5}{|c|}{ Independent Variables } \\
\hline Change Community Bank Deposits (\$000) & 38,546 & 173,662 & $-905,567$ & $2,819,864$ \\
\hline Minnesota & 0.31 & 0.46 & 0.00 & 1.00 \\
\hline Montana & 0.20 & 0.40 & 0.00 & 1.00 \\
\hline North Dakota & 0.18 & 0.39 & 0.00 & 1.00 \\
\hline Wyoming & 0.08 & 0.28 & 0.00 & 1.00 \\
\hline Non-metro Urban & 0.38 & 0.49 & 0.00 & 1.00 \\
\hline Non-metro Rural & 0.46 & 0.50 & 0.0 & 1.00 \\
\hline Change Cropland / Farmland & 0.02 & 0.04 & -0.12 & 0.31 \\
\hline Change Per Capita Personal Income (\$) & 7,076 & 8,239 & $-13,460$ & 85,878 \\
\hline Change Population & 1,150 & 3,909 & $-1,616$ & 58,202 \\
\hline $\begin{array}{l}\text { Change Neigh. Comm. Bank Deposits } \\
\qquad(\$ 000)\end{array}$ & 41,690 & 93,717 & $-255,583$ & 732,922 \\
\hline \multicolumn{5}{|c|}{ Instruments } \\
\hline Change Crude Oil Withdrawals (barrels) & 234,116 & $2,778,965$ & $-8,209,434$ & $48,791,395$ \\
\hline $\begin{array}{c}\text { Change Lag Comm. Bank Deposits }(\$ 000) \\
\text { Change Ave State Comm. Bank Den }\end{array}$ & 33,380 & 167,798 & $-1,318,465$ & $2,819,864$ \\
\hline$(\$ 000)$ & 38,546 & 37,934 & $-11,980$ & 96,985 \\
\hline
\end{tabular}

Descriptive statistics of some control variables are suppressed for brevity.

\section{RESULTS}

\subsection{Instrumental Variable Regressions}

Table 2 shows that oil withdrawals have a positive, statistically significant effect on community bank deposits in the specification in which total agricultural sales is the dependent variable $(p$-value $<.05)$. Oil withdrawals do not have a statistically significant impact on community bank deposits in the DTC agricultural sales specification. This latter specification includes fewer observations, as DTC agricultural sales are redacted in some counties in the Census of Agriculture due to disclosure concerns. Thus, oil withdrawals are a valid instrument with regards to total agricultural sales, but not a valid instrument in the DTC agricultural sales specification. The lag of community bank deposits and state-level community bank deposits are both statistically significant in the first-stage regression with regard to DTC agricultural sales ( $p$ value $<.01)$.

Furthermore, both oil withdrawals and state-level community bank deposits are statistically significant when they are both included as instruments and when the dependent variable is total agricultural sales. An overidentification test indicates whether the instruments are correlated with the error term in Equation (1). In Table 2, the $F$-value is statistically insignificant with a $p$-value of .47 , which provides evidence in support of the validity of both instruments.

(c) Southern Regional Science Association 2017. 
Table 2: Instrumental Variable Results

\begin{tabular}{|c|c|c|c|c|c|}
\hline Specification Variable & $\begin{array}{l}\text { Total Ag. } \\
\text { Sales }\end{array}$ & $\begin{array}{l}\text { Total Ag. } \\
\text { Sales }\end{array}$ & $\begin{array}{l}\text { DTC Ag. } \\
\text { Sales }\end{array}$ & $\begin{array}{l}\text { DTC Ag. } \\
\text { Sales }\end{array}$ & $\begin{array}{l}\text { DTC Ag. } \\
\text { Sales }\end{array}$ \\
\hline \multicolumn{6}{|c|}{ First Stage Regression Results. Dep. Var.: Comm. Bank Deposits } \\
\hline Oil Withdrawals Coefficient & $0.006^{* *}$ & $0.006^{* *}$ & 0.0015 & - & - \\
\hline $\begin{array}{l}5 \text { Year Lag Community Bank } \\
\text { Deposits Coefficient }\end{array}$ & - & - & - & $-0.914 * * *$ & - \\
\hline $\begin{array}{l}\text { Ave. State Community Bank } \\
\text { Deposits Coefficient }\end{array}$ & - & $0.932 * * *$ & - & - & $0.968 * * *$ \\
\hline Regression F-Statistic & $5.99 * * *$ & $6.93 * * *$ & $4.32 * * *$ & $36.76^{* * *}$ & $5.39 * * *$ \\
\hline \multicolumn{6}{|c|}{ Pertinent IV Statistics } \\
\hline $\begin{array}{l}\text { Hausman Exogeneity P-Value } \\
\text { Overidentifying Restrictions F- }\end{array}$ & 0.01 & 0.11 & - & 0.57 & 0.80 \\
\hline $\begin{array}{c}\text { Value } \\
\text { Overidentifying Restrictions P- }\end{array}$ & - & 0.52 & - & - & - \\
\hline Value & - & 0.47 & - & - & - \\
\hline \multicolumn{6}{|c|}{ IV Results } \\
\hline Community Bank Coefficient & -0.155 & -0.084 & - & $0.0003 * * *$ & 0.00008 \\
\hline Regression F-Statistic & $16.58 * * *$ & $20.55 * * *$ & - & $2.32 * * *$ & 1.53 \\
\hline
\end{tabular}

Table 2 shows that the $p$-value of the coefficient corresponding to the first-stage residuals in the second-stage Hausman test regression is statistically significant when the dependent variable is total agricultural sales and the instrument is oil withdrawals. However, the Hausman coefficient is statistically insignificant for this dependent variable when both instruments are used. The Hausman test coefficient is also statistically insignificant in the specifications with DTC agricultural sales as the dependent variable when either the lag of community bank deposits or average state-level community bank deposits are used as instruments.

The second-stage regression results in Table 2 show that the community bank coefficient is statistically insignificant for the specifications in which total agricultural sales is the dependent variable. The parameter estimates for community bank deposits in the second-stage regressions are statistically significant and positive when DTC agricultural sales is the dependent variable and the lag of community bank deposits is used as an instrument ( $p$-value $<.01$ ), although it is insignificant when state-level community bank deposits is the instrument.

\subsection{First Difference Regressions}

I present first difference (FD) results in Table 3. Even though community bank deposits may be endogenous with total agricultural sales as the dependent variable, I report the results of this FD specification for consistency. In Specification 1, community bank deposits have a statistically insignificant impact on total agricultural sales. 
Table 3: First Difference Regressions - Both Periods

\begin{tabular}{|c|c|c|c|c|}
\hline Specification Number & 1 & 2 & 3 & 4 \\
\hline Dependent Variable & $\begin{array}{c}\text { Total Ag. } \\
\text { Sales }\end{array}$ & $\begin{array}{c}\text { DTC Ag. } \\
\text { Sales }\end{array}$ & $\begin{array}{c}\text { DTC Ag. } \\
\text { Sales }\end{array}$ & $\begin{array}{c}\text { DTC Ag. } \\
\text { Sales }\end{array}$ \\
\hline Specification Description & Main Model & $\begin{array}{l}\text { Inc. and Pop. } \\
\text { Included }\end{array}$ & $\begin{array}{c}\text { Interaction } \\
\text { Included }\end{array}$ & $\begin{array}{c}\text { Spatial Term } \\
\text { Included }\end{array}$ \\
\hline Dummy 2007-2012 & $\begin{array}{c}22,033 * * * \\
(3,495)\end{array}$ & $\begin{array}{c}-37.97 * * \\
(18.15)\end{array}$ & $\begin{array}{l}-33.17 \\
(21.34)\end{array}$ & $\begin{array}{c}-28.73 * \\
(16.98)\end{array}$ \\
\hline Minnesota Dummy & $\begin{array}{c}18,497 * * * \\
(5,821)\end{array}$ & $\begin{array}{c}15.3 \\
(30.01)\end{array}$ & $\begin{array}{c}13.08 \\
(30.31)\end{array}$ & $\begin{array}{c}1.13 \\
(30.31)\end{array}$ \\
\hline Montana Dummy & $\begin{array}{c}-29,148 * * * \\
(4,421)\end{array}$ & $\begin{array}{c}34.17 \\
(23.85)\end{array}$ & $\begin{array}{c}34.02 \\
(24.83)\end{array}$ & $\begin{array}{l}46.75^{*} \\
(24.63)\end{array}$ \\
\hline North Dakota Dummy & $\begin{array}{c}25,649 * * * \\
(5,891)\end{array}$ & $\begin{array}{c}-16.2 \\
(25.61)\end{array}$ & $\begin{array}{l}-13.59 \\
(27.15)\end{array}$ & $\begin{array}{l}-24.97 \\
(25.76)\end{array}$ \\
\hline Wyoming Dummy & $\begin{array}{c}-33,645^{* * *} \\
(5,126)\end{array}$ & $\begin{array}{c}-3.65 \\
(29.58)\end{array}$ & $\begin{array}{c}-7.96 \\
(29.68)\end{array}$ & $\begin{array}{c}-8.28 \\
(30.33)\end{array}$ \\
\hline Non-metro Urban Dummy & $\begin{array}{c}12,794 * * \\
(6,447)\end{array}$ & $\begin{array}{c}9.68 \\
(38.73)\end{array}$ & $\begin{array}{c}9.76 \\
(44.63)\end{array}$ & $\begin{array}{c}10.85 \\
(38.93)\end{array}$ \\
\hline Non-metro Rural Dummy & $\begin{array}{c}466 \\
(6,501)\end{array}$ & $\begin{array}{c}22.92 \\
(36.37)\end{array}$ & $\begin{array}{c}19.97 \\
(39.73)\end{array}$ & $\begin{array}{c}19.22 \\
(36.06)\end{array}$ \\
\hline Change Comm Bank Dep & $\begin{array}{l}-0.001 \\
(0.020)\end{array}$ & $\begin{array}{c}0.00016 * * * \\
(0.00006)\end{array}$ & $\begin{array}{c}0.00021 * * * \\
(0.00006)\end{array}$ & $\begin{array}{c}0.00008 \\
(0.00005)\end{array}$ \\
\hline Change Cropland / Farmland & $\begin{array}{l}75,927 * \\
(40,219)\end{array}$ & $\begin{array}{l}514.16^{* *} \\
(255.37)\end{array}$ & $\begin{array}{c}502.37 * * \\
(250.38)\end{array}$ & $\begin{array}{l}593.47 * * \\
(252.51)\end{array}$ \\
\hline Change Per Capita Income & & $\begin{array}{l}-0.0012 * \\
(0.0007)\end{array}$ & $\begin{array}{c}-0.001 \\
(0.0012)\end{array}$ & $\begin{array}{c}-0.0018 * * \\
(0.0008)\end{array}$ \\
\hline Change Population & & $\begin{array}{c}0.007 \\
(0.004)\end{array}$ & $\begin{array}{c}0.006 \\
(0.005)\end{array}$ & $\begin{array}{c}0.005 \\
(0.004)\end{array}$ \\
\hline CB Dep * NM Urban & & & $\begin{array}{l}-0.0001 \\
(0.0002)\end{array}$ & \\
\hline CB Dep * NM Rural & & & $\begin{array}{l}-0.0001 \\
(0.0002)\end{array}$ & \\
\hline CB Dep * 2007-2012 Dummy & & & $\begin{array}{l}-0.0001 \\
(0.0002)\end{array}$ & \\
\hline Change Comm Bank Dep Neighbor & & & & $\begin{array}{c}0.00043 * * \\
(0.00018)\end{array}$ \\
\hline R-Squared & 0.27 & 0.05 & 0.06 & 0.08 \\
\hline F-Statistic & $22.52 * * *$ & $2.21 * *$ & $1.86^{* *}$ & $3.23 * * *$ \\
\hline Observations & 550 & 434 & 434 & 434 \\
\hline
\end{tabular}

*** indicates significant at $99 \%$ confidence. $* *$ indicates significant at $95 \%$ confidence. $*$ indicates significant at $90 \%$ confidence. Parameter estimate is on same line as the variable name, with corresponding robust standard error reported beneath.

(c) Southern Regional Science Association 2017. 
DTC agricultural sales is the dependent variable in Specifications 2, 3, and 4. In Specifications 2 and 3, the community bank deposit coefficient is positive and statistically significant $(p$-value $<.01)$. The coefficient magnitudes indicate that, on average, a $\$ 1$ million county-level increase in community bank deposits increases DTC agricultural sales in the same county by $\$ 160$ or $\$ 210$, respectively. ${ }^{3}$ The community bank coefficient is positive but statistically insignificant in Specification 4, while the coefficient on community bank deposits in neighboring counties is positive and significant $(p$-value $<.01)$. The latter coefficient implies that a $\$ 1$ million increase in community bank deposits in neighboring counties increases DTC agricultural sales in a county by $\$ 430$.

The change in the proportion of harvested cropland relative to total farmland is statistically significant and positive in each of the specifications in Table 3, which is consistent with the expected sign. The 2007-2012 dummy variable is negative and statistically significant in Specifications 2 and 4, suggesting that DTC agricultural sales declined during that time period relative to the 2002-2007 interval, ceteris paribus. The per capita income coefficient is negative and statistically significant in Specifications 2 and 4. The non-metropolitan urban and nonmetropolitan rural dummy variables are statistically insignificant in Specifications 2, 3, and $4 .^{4}$ Furthermore, the three interaction terms are each statistically insignificant in Specification 3.

In Table 4, the F-statistic and R-squared statistic both indicate that the model provides a better explanation of trends in DTC agricultural sales for the 2002-2007 interval than between 2007 and 2012. The signs varied on several coefficients between the time periods, which explains why the Chow test is statistically significant. The community bank deposit coefficient is not statistically significant in the 2007-2012 regression in Table 4, which is consistent with Specification 3 in Table 3. Nonetheless, the community bank coefficient is positive and statistically significant in the 2002-2007 time period regression $(p$-value $<.01)$ with the same coefficient magnitude as in Specification 2 in Table 3.

The change in cropland as a percentage of farmland also has a positive impact during the 2007-2012 period, but is insignificant during the 2002-2007 period. Table 4 also shows that per capita income has a negative impact $(p$-value $<.05)$ while population $(p$-value $<.05)$, nonmetropolitan rural counties $(p$-value $<.05)$, and non-metropolitan urban counties $(p$-value $<.05)$ have a positive impact on DTC agricultural sales during the 2002-2007 interval. However, with the exception of the nonmetropolitan urban dummy, these coefficients are not statistically significant in the 2007-2012 regression.

\section{DISCUSSION}

I find that community bank deposits are exogenous with regard to DTC agricultural sales as the dependent variable, which can be intuited from the modest magnitude of DTC agricultural sales in the region. The Hausman tests of whether community bank deposits are exogenous with regard to total agricultural sales are inconclusive, since the statistical significance of the coefficient depends on the choice of instrument.

\footnotetext{
${ }^{3}$ A $\$ 1$ million increase represents a relatively modest increase, as the standard deviation of county-level changes in community bank deposits is $\$ 174$ million (Table 1 ).

${ }^{4}$ While not reported in Table 3, I also estimate a specification with eight dummy variables that provide a more detailed delineation of county characteristics of population sizes and proximity to metropolitan areas as a further robustness check. However, all of the dummy variables are statistically insignificant in the specification with the more granular county classifications.
}

(c) Southern Regional Science Association 2017. 
Table 4: DTC Sales First Difference Regressions - Distinct Periods

\begin{tabular}{ccccc}
\hline \hline Time Period & \multicolumn{2}{c}{$2007-2012$} & \multicolumn{2}{c}{ 2002-2007 } \\
\hline & $\begin{array}{c}\text { Parameter } \\
\text { Estimate }\end{array}$ & $\begin{array}{c}\text { Robust } \\
\text { Std. Err. }\end{array}$ & $\begin{array}{c}\text { Parameter } \\
\text { Estimate }\end{array}$ & $\begin{array}{c}\text { Robust } \\
\text { Std. Err. }\end{array}$ \\
\hline Intercept & 2.72 & $(52.94)$ & -59.92 & $(52.86)$ \\
Minnesota Dummy & 28.93 & $(41.32)$ & -35.69 & $(41.12)$ \\
Montana Dummy & $97.82^{* * *}$ & $(33.65)$ & -34.18 & $(32.99)$ \\
North Dakota Dummy & -14.52 & $(47.38)$ & -26.33 & $(34.04)$ \\
Wyoming Dummy & $78.29 *$ & $(42.26)$ & -67.01 & $(41.30)$ \\
Non-metro Urban Dummy & $-97.38^{*}$ & $(54.07)$ & $123.18^{* *}$ & $(54.92)$ \\
Non-metro Rural Dummy & -74.32 & $(50.78)$ & $121.69 * *$ & $(50.84)$ \\
Change Comm Bank Dep & -0.00007 & $(0.00013)$ & $0.00016^{* * *}$ & $(0.00004)$ \\
Change Cropland / Farmland & $1,140.44^{* * *}$ & $(422.46)$ & 248.38 & $(241.24)$ \\
Change Per Capita Income & 0.0012 & $(0.0015)$ & $-0.0029 * *$ & $(0.0011)$ \\
Change Population & -0.005 & $(0.005)$ & $0.022^{* *}$ & $(0.009)$ \\
\hline R-Squared & \multicolumn{2}{c}{0.08} & 0.15 \\
F-Statistic & \multicolumn{2}{c}{$3.70^{*}$} & $3.62 * * *$ \\
Observations & 215 & 219 \\
\hline
\end{tabular}

Chow Structural Change Statistic $2.86 * * *$

*** indicates significant at $99 \%$ confidence. $* *$ indicate significant at $95 \%$ confidence. $*$ indicates significant at $90 \%$ confidence.

Nonetheless, community bank deposits do not have a statistically significant effect on total agricultural sales in either the first difference or instrumental variable regressions. This may occur because loans for larger farms in conventional commodity markets are more straightforward to evaluate. For instance, the extensive subsidies available for commodity crop production are an important source of collateral for bankers, there is greater price transparency in commodity markets due to the existence of exchange-traded futures contracts, and/or the resulting agricultural products are sold into national or global supply chains with established purchasers. This suggests that personal relationships with a borrower and/or specific knowledge of a community may be relatively less important in extending and servicing a loan, and that financing for larger farms could occur from a nonlocal source or that they may be capable of self-financing if they are part of a larger corporation.

The positive impact of community bank deposits on DTC agricultural sales could occur because the knowledge possessed by community bank lenders of local market conditions enables them to lend effectively. Personal relationships and knowledge of local DTC agricultural markets can be valuable in evaluating a loan application, since market prices and conditions are not as widely disseminated as in conventional agricultural markets.

The magnitude of the coefficients in Specifications 2 and 3 of Table 3 correspond to elasticity values of 0.27 and 0.35 , respectively, when using 2012 county-level average values for DTC agricultural sales and community bank deposits. Another interpretation of the coefficient magnitudes is that the mean increase in community bank deposits, when multiplied by the parameter estimates from Specifications 2 and 3, explain 32 percent and 43 percent, respectively, of the mean increase in DTC agricultural sales. The same calculation finds that the maximum

(c) Southern Regional Science Association 2017. 
increase in community bank deposits comprise 31 percent and 41 percent, respectively, of the maximum increase in DTC agricultural sales. These corresponding percentages are 12 percent and 15 percent, respectively, for the minimum increases.

I also find a negative and statistically significant coefficient on the per capita income coefficient. The sign on this coefficient is hypothesized as ambiguous a priori. Higher incomes increase the capability of consumers to purchase food with the quality attributes that they desire, yet they also increase the opportunity cost of time in shopping for and preparing food for at-home consumption. Previous research has found the relationship between income and local food purchases to be inconclusive (Martinez et al., 2010; Byker et al., 2012). O'Hara and Low (2016) found that DTC agricultural sales have experienced a high elasticity with respect to income in the Northeast between 1992 and 2012. Differences may arise in the region of this study because, during this shorter period, per capita income increased sharply and in some areas these high increases occurred in counties in which income levels were already high. Also, income was not statistically significant when community bank deposits was removed as an independent variable, and could be significant with a negative sign when it is included since community bank deposits and income are positively correlated.

The results also suggest that community bank deposits had a more pronounced impact on DTC agricultural sales from 2002 to 2007 than from 2007 to 2012. Peirce, Robinson, and Stratmann (2014) found that small banks limited their product offerings after the passage of the Dodd-Frank Act in 2010 due to increased compliance costs. Thus, community banks may have been less willing to service DTC market activity between 2007 and 2012 than they were between 2002 and 2007. Also, community bank deposits in the five-state region increased by only half as much between 2007 and 2012 as they did between 2002 and 2007, which suggests that their impact on DTC agricultural sales may be more pronounced for larger increases.

\section{CONCLUSION}

This study is one of the first to test whether changes in the structure of the commercial banking sector have influenced sales from farms in nonconventional markets. My results can inform how to target grant and loan programs developed by government officials and/or private investors that are intended to enhance DTC agricultural markets. Specifically, the results suggest that local food policies may be more impactful in regions without a strong community banking presence ceteris paribus, and vice versa.

The generalizability of the results to the rest of the U.S. is unclear. Small banks are less prominent in more densely populated regions while DTC agricultural marketing may be more viable in these areas since there is a larger customer base. Thus, other channels may be prominent in providing financing to the sector, such as brokers with knowledge of specialized farming practices (like sustainable agriculture organizations) and/or community development financial institutions. These other credit sources may require consideration in evaluating credit availability to farms selling through non-traditional marketing channels in other parts of the U.S.

This study uses community bank deposits as a proxy for available credit, since the FDIC community bank definition entails that there must be threshold levels of deposits and loans relative to assets. However, future research could examine the association between accepting deposits and extending credit by community banks in further detail, particularly in the context of DTC agricultural markets and other non-conventional agricultural markets. 


\section{REFERENCES}

Ahearn, Mary, and James Sterns. (2013) "Direct-to-Consumer Sales of Farm Products: Producers and Supply Chains in the Southeast," Journal of Agricultural and Applied Economics, 45, 497-508.

Berger, Allen N., William Goulding, and Tara Rice. (2014) "Do Small Businesses Still Prefer Community Banks?," Journal of Banking and Finance, 44, 264-278.

Briggeman, Brian C., Charles A. Towe, and Mitchell J. Morehart. (2009) "Credit Constraints: Their Existence, Determinants, and Implications for U.S. Farm and Nonfarm Sole Proprietorships," American Journal of Agricultural Economics, 91, 275-289.

Brown, Jason P., Stephan Goetz, Mary C. Ahearn, and Chyi-lyi (Kathleen) Liang. (2014) "Linkages Between Community Focused Agriculture, Farm Sales, and Regional Growth," Economic Development Quarterly, 28, 5-16.

Byker, Carmen, Justin Shanks, Sarah Misyak, and Elena Serrano. (2012) “Characterizing Farmers' Market Shoppers: A Literature Review," Journal of Hunger and Environmental Nutrition, 7, 38-52.

DeYoung, Robert, Dennis Glennon, Peter Nigro, and Kenneth Spong. (2012) "Small Business Lending and Social Capital: Are Rural Relationships Different?" The University of Kansas Center for Banking Excellence CBE Research Paper \#2012-1: Lawrence, Kansas.

Federal Deposit Insurance Corporation (FDIC). (2012) FDIC Community Banking Study. Accessed on November 25, 2016, at https://www.fdic.gov/regulations/resources/cbi/study.html.

- (2015a) Summary of Deposits. Accessed on November 25, 2016, at https://www5.fdic.gov/sod/.

. (2015b) Summary of Deposits Reporting Instructions. Accessed on November 25, 2016, at https://www5.fdic.gov/sod/pdf/sod_instructions.pdf.

. (2015c) FDIC Community Banking Study Reference Data. Accessed on November 25, 2016, at https://www.fdic.gov/regulations/resources/cbi/data.html.

Gloy, Brent A., Michael A. Gunderson, and Eddy L. Ladue. (2005) "The Costs and Returns of Agricultural Credit Delivery," American Journal of Agricultural Economics, 87, 703-716.

Government Accountability Office (GAO). (2012) "Community Banks and Credit Unions: Impact of the Dodd-Frank Act Depends Largely on Future Rule Makings." GAO-12-881: Washington, D.C.

Hartarska, Valentina and Dennis Nadolnyak. (2012) "Financing Constraints and Access to Credit in a Postcrisis Environment: Evidence from New Farmers in Alabama," Journal of Agricultural and Applied Economics, 44, 607-621.

Hughes, David W., Cheryl Brown, Stacy Miller, and Tom McConnell. (2008) "Evaluating the Economic Impact of Farmers' Markets Using an Opportunity Cost Framework," Journal of Agricultural and Applied Economics, 40, 253-265.

Hughes, David W., and Olga Isengildina-Massa. (2015) “The Economic Impact of Farmers' Markets and a State Level Locally Grown Campaign," Food Policy, 54, 78-84.

(c) Southern Regional Science Association 2017. 
Institute for Local Self-Reliance (ILSR) (2015) Accessed on November 25, 2016, at https://ilsr.org/rule/bank-of-north-dakota-2/.

Kandrac, John. (2014) "Bank Failure, Relationship Lending, and Local Economic Performance," Federal Reserve Board Finance and Economics Discussion Series 2014-41: Washington, D.C.

Kauffman, Nathan, and Maria Akers. (2013) "Agricultural Lending Shifts to Large Banks," Federal Reserve Bank of Kansas City, Agricultural Finance Databook: Kansas City, Missouri.

Key, Nigel D. and Michael J. Roberts. (2007) "Do Government Payments Influence Farm Size and Survival?," Journal of Agricultural and Resource Economics, 32, 330-349.

Kodrzycki, Yolanda K. and Tal Elmatad. (2011) "The Bank of North Dakota: A Model for Massachusetts and Other States?," Federal Reserve Bank of Boston Public Policy Discussion Paper 11-2: Boston.

Kravchenko, Nataliia, Stephan Weiler, and Ronnie J. Philips. (2011) "Information Externalities and Small Business Lending by Banks: A Comparison of Urban and Rural Counties in the U.S." SSRN Working Paper 1968965.

Low, Sarah A., and Stephen Vogel. (2011) "Direct and Intermediated Marketing of Local Foods in the United States," U.S. Department of Agriculture, Economic Research Service, Economic Research Report Number 128: Washington, D.C.

Lux, Marshall, and Robert Greene. (2015) "The State and Fate of Community Banking," Mossavar-Rahmani Center for Business and Government Working Paper No. 37: Cambridge, MA.

MacDonald, James M., Penni Korb, and Robert A. Hoppe. (2013) "Farm Size and the Organization of U.S. Crop Farming," U.S. Department of Agriculture, Economic Research Service, Economic Research Report Number 152: Washington, D.C.

Martinez, Steve, Michael Hand, Michelle Da Pra, Susan Pollack, Katherine Ralston, Travis Smith, Stephen Vogel, Shellye Clark, Luanne Lohr, Sarah Low, and Constance Newman. (2010) "Local Food Systems: Concepts, Impacts, and Issues," U.S. Department of Agriculture, Economic Research Service, Economic Research Report Number 97: Washington, D.C.

O’Hara, Jeffrey K. (2012) “Insuring Diversified Fruit and Vegetable Farms,” Choices, 27 (Quarter 3). Accessed on November 25, 2016, at http://choicesmagazine.org/choicesmagazine/submitted-articles/insuring-diversified-fruit-and-vegetable-farms.

O'Hara, Jeffrey K., and Sarah A. Low. (2016) “The Influence of Metropolitan Statistical Areas on Direct-to-Consumer Agricultural Sales of Local Food in the Northeast," Agricultural and Resource Economics Review, 1-24.

Peirce, Hester, Ian Robinson, and Thomas Stratmann. (2014) "How Are Small Banks Faring Under Dodd-Frank?," Mercatus Center at George Mason University Working Paper No. 14-05: Arlington, VA.

Roberts, Michael J., and Nigel Key. (2008) “Agricultural Payments and Land Concentration: A Semiparametric Spatial Regression Analysis," American Journal of Agricultural Economics, 90, 627-643.

(C) Southern Regional Science Association 2017. 
Sabasi, Darlington, and Lyudmyla Kompaniyets. (2015) "Impact of Credit Constraints on Profitability and Productivity in U.S. Agriculture," Paper presented at the Agricultural \& Applied Economics Association's 2015 Annual Meeting: San Francisco, CA.

Tarullo, Daniel K. (2014) "A Tiered Approach to Regulation and Supervision of Community Banks," Speech to Community Bankers Symposium in Chicago, IL. Accessed on November 25, 2016, at http://www.federalreserve.gov/newsevents/speech/tarullo20141107a.htm\#fn4.

United States Bureau of Economic Analysis (BEA). (2015) Regional Economic Accounts. Accessed on November 25, 2016, at http://bea.gov/regional/index.htm.

United States Bureau of Labor Statistics (BLS). (2015) Consumer Price Index, All Urban Consumers, All Items, 1982-84=100, U.S. City Average, Not Seasonally Adjusted, Annual Average. Accessed on November 25, 2016, at http://data.bls.gov/cgi-bin/surveymost?cu.

United States Department of Agriculture (USDA). (2014) Census of Agriculture. Accessed on November 25, 2016, at http://www.agcensus.usda.gov/.

United States Department of Agriculture Economic Research Service (USDA ERS). (2013) RuralUrban Continuum Codes. Accessed on November 25, 2016, at http://www.ers.usda.gov/dataproducts/rural-urban-continuum-codes.aspx\#.UYJuVEpZRvY.

. (2014) County-level Oil and Gas Production in the U.S. Accessed on November 25, 2016, at http://www.ers.usda.gov/data-products/county-level-oil-and-gas-production-in-the-us.aspx.

. (2015) Farm Income and Wealth Statistics: Balance Sheet. Accessed on November 25, 2016, at http://www.ers.usda.gov/data-products/farm-income-and-wealth-statistics/balancesheet.aspx.

White, T. Kirk, and Robert A. Hoppe. (2012) "Changing Farm Structure and the Distribution of Farm Payments and Federal Crop Insurance," U.S. Department of Agriculture, Economic Research Service, Economic Information Bulletin Number 91: Washington, D.C.

Wooldridge, Jeffrey M. (2002) Econometric Analysis of Cross Section and Panel Data. MIT Press: Cambridge, Massachusetts. 